\title{
Procedure Sequence Number
}

National Cancer Institute

\section{Source}

National Cancer Institute. Procedure Sequence Number. NCI Thesaurus. Code C117506.

An identifier that describes the relative position of procedures within a series. 